\title{
ANTIFUNGAL ACTIVITY OF BACTERIA OF THE GENUS BACILLUS AND STREPTOMYCES ISOLATED FROM THE SOIL OF THE REPUBLIC OF MOLDOVA
}

\author{
V. Shubina ${ }^{1}$, M. Birsa ${ }^{2}$, S. Burtseva ${ }^{2}$ \\ ${ }^{1}$ Institute of Genetics, Physiology and Plant Protection, \\ 20 Padurii str., Chisinau, MD-2002, Republic of Moldova \\ ${ }^{2}$ Institute of Microbiology and Biotechnology, \\ 1 Academiei str., Chisinau, MD-2028, Republic of Moldova \\ e-mail: burtseva.svetlana@gmail.com
}

\begin{abstract}
Aim. The article deals with the results of research, the aim of which was to determine antifungal activity of the strains Bacillus and Streptomyces genera, in relation to phytopathogenic fungi, widely distributed in Moldova. Methods. Strains were grown on classical agar media, the antifungal activity was determined by the method of agar blocks with test cultures - phytopathogenic fungi. Biological standard was the bacterium B. subtilis 26D. In the experiments on the germination of A. alternata conidia, 5 bacterial cultures grown in liquid nutrient medium No. 2. Results. It is established that all bacteria of genus Bacillus exhibit antifungal activity against test cultures, but in varying degrees. The growth of B. cinerea and F. oxysporum was least inhibited. Strain B. subtilis S4 most actively suppressed the growth of S. sclerotiorum. Strain Streptomyces sp. 10 is able to completely suppress the growth of A. alternata and B. cinerea, and the strain $S$. sp 9 completely suppressed the growth of S. sclerotiorum. Strains 9, 12, and 66 actively inhibited growth of F. culmorum (the radius of the zones was 16.0-20.0 mm), and strain $S . \mathrm{sp} .185$ against F. oxysporum (zones up to $28.0 \mathrm{~mm}$ ). The strongest inhibitory effect on the germination of A. alternata conidia had strain $S 2$. Conclusions. A comparative assessment of the antifungal activity of B. subtilis revealed a strain with the most pronounced antifungal properties. The investigated liquid cultures of bacteria of the genus Bacillus exhibited a special fungicidal effect on the germination of A. alternata conidia. Among 7 strains of streptomycetes tested, particular interest had S. sp. 10, capable to completely suppressing the growth of A. alternata and B. cinerea, and the strain S. sp. 9 - completely inhibits the growth of $S$. sclerotiorum, as well as the strain S. sp. 185 actively inhibited the growth of F. oxysporum and the strain $S$. sp. $10-A$. solani.
\end{abstract}

Keywords: Bacillus, Streptomyces, germination of conidia, phytopathogens.

The biological method is currently an important element in the technological process of growing vegetable crops. In global production only $10 \%$ are biopreparations intended for plant protection against pests, for control of plant pathogens $-4.6 \%$ and for control of weeds $-1.3 \%$ [1].

According to Bayer company and the Ministry of Agriculture of Japan, resistance of phytopathogenic fungi against fungicides has been increasing in recent years. Thus, between 20 species of phytopathogens, resistance to 15 fungicides has been determined. Considering the fact that biological preparations are less universal than chemical agents, it is necessary to expand the arsenal of biological agents [2]. 
Biological agents, in particular bacteria of the genus Bacillus have basic role in biological plant protection against diseases. The antagonistic activity of this bacterium is manifested against a wide range of phytopathogens, which affect a large range of crops. Active bacterial culture inhibits the multiplication of pathogenic fungi and bacteria due the produced metabolites. The use of such drugs for protection of vegetable crops (cabbage, cucumber, tomato) and berry fields is of great economic importance [3]. The use of Bactofit on the basis of the IPM-215 strain of B. subtilis reduced the development of root rot of winter wheat by 4 times and powdery mildew by 10 times. Preparation of Phytosporin-M on the basis of strain 26D B. subtilis proved effective in combating late blight and alternaria of potato. Under storage conditions, postvegetative biological efficacy was retained in potato tubers obtained from sites treated with Fitosporin-M [4].

The purposeful selection of bacteria-antagonists against sugar beet diseases during the winter storage period was carried out by Belarusian scientists. The bacteria of genus Bacillus was active against Botrytis cinerea, Alternaria tenuis, Fusarium culmorum, F. redolens, Penicillium expansum, Sclerotinia sclerotiorum, which cause rot. Metabolites of bacteria showed an inhibitory effect on spore germination and the development of the mycelium of phytopathogenic fungi. The culture fluid with metabolites caused deformation of spores and growth tubes of $P$. expansum and $B$. cinerea fungi accompanied by vacuolization and the appearance of tumor-like blisters. Under the influence of antagonists, the prevalence of rot on root crops decreased by $25-30 \%$ in comparison with control, the development of the disease by $13 \%$ low [5].

The inhibition of spore germination of the Fusarium udum was also observed by action of Streptomyces sp. A6 [6].

In search of microbial agents against the late blight burn of pepper from the rhizosphere, were obtained 6 bacterial isolates and 10 isolates of actinomycetes which inhibit the growth of Phytophthora capsici. Bacterial isolate B4 and actinomycete isolate a10 stimulated the growth of pepper and suppressed the growth of the pathogen mycelium by $79.5 \%$ and $74.5 \%$, respectively, and the spore germination was $92.8 \%$ and $83.3 \%$, respectively. Treatment of pepper plants with mixed inoculum suppressed the development of the disease by $72.5 \%$ in the greenhouse and by $76.2 \%$ in the field [7].

In paper are shown results of the determination of the antagonistic activity of the bacteria of genera Bacillus and Streptomyces, isolated from rizosphere of tomato and from the soil samples of the central part of Moldova, against causative agents of agricultural diseases.

Material and methods. Strains of genus Streptomyces were isolated from the soil samples of the central part of Moldova. Bacteria of genus Bacillus were isolated from the rhizosphere of tomatoes. Special attention was paid to strains which grown well on classical agar media, well-sporulated and had antimicrobial activity. Antifungal activity was determined by classical disk diffusion method with use of agar blocks. Petri dishes were placed in thermostat at a temperature of $28^{\circ} \mathrm{C}$, the growth radius of the antagonistic action zone was measured after 5-7 days [8]. As test cultures served strains of phytopathogenic fungi: Alternaria alternata 2-14; Aalternaria alternata LG14; 
Alternaria solani; Rhizoctonia solani; Botrytis cinerea; Fusarium culmorum; Fusarium solani; Fusarium oxysporum; Sclerotinia sclerotiorum; Aspergillus niger; Botrytis cinerea. Test cultures of micromycetes were isolated from tomato plants with obvious signs of disease, identified by classical methods and confirmed by PCR analysis conducted at the Institute of Genetics, Physiology and Plant Protection (Laboratory of Molecular Genetics). All studied strains are stored in the collection of the Laboratory of Phytopathology and Biotechnology of the above-mentioned Institute. In experiments of testing bacterial cultures, as biological standard served strain Bacillus subtilis 26D (producer of the Russian biopreparation Fitosporin).

In the germination test for conidia of Alternaria alternata, the same 5 bacterial cultures were used. Cultures were grown on liquid nutrient medium No. 2 for 2 days. Incubation temperature $-28^{\circ} \mathrm{C}$. As control served water and a nutrient medium in the same dilution as the culture liquids. Culture characteristics of the growth were taken into account after 2, 3, 4, 5, 6, 7, 24, 36 and 48 hours exposure. The statistical data analysis method was applied $(\mathrm{p}=0.05)$.

Results. Analysis of the obtained data on the detection of the antifungal activity of the bacteria genus Bacillus showed that all bacteria were active against test cultures, but in varying degrees (Table 1). Weaker in some positions were bacteria of $B$. subtilis-S4 and B. subtilis-S22. The least was growth inhibition of test cultures Botrytis cinerea and Fusarium oxysporum. The culture of B. subtilis-S4 although demonstrated a less antifungal effect against to all studied pathogens (except for Sclerotinia sclerotiorum, which had a zone of growth inhibition with a radius of $31.5 \mathrm{~mm}$, but it was stable). The S2 culture in its action against different isolates of Alternaria, in one case exceeded the activity of the biological standard by $28 \%$, and in the other only by $7 \%$. Against Rhizoctonia solani, Alternaria solani and Fusarium solani activity was higher by $13 \%, 14 \%$ and $18 \%$ (respectively). The effect of the S16 culture against Rhizoctonia solani exceeded the standard by $3 \%$, and Alternaria alternata by $18 \%$.

All cultures showed a stable antagonistic effect.

Table 1

Antifungal action of bacteria of genus Bacillus (the radius of zone of growth inhibition of test cultures, $\mathbf{m m}$ )

\begin{tabular}{|l|c|c|c|c|c|}
\hline Test cultures & $\begin{array}{c}\text { B.subtilis - } \\
\text { 26D }\end{array}$ & $\begin{array}{c}\text { B.subtilis - } \\
\text { S16 }\end{array}$ & $\begin{array}{c}\text { B.subtilis } \\
- \text { S2 }\end{array}$ & $\begin{array}{c}\text { B.subtilis } \\
- \text { S4 }\end{array}$ & $\begin{array}{c}\text { B.subtilis - } \\
\text { S22 }\end{array}$ \\
\hline A. alternata 2-14 & $19.7 \pm 0.8$ & $17.0 \pm 2.0$ & $21.0 \pm 0.0$ & $20.3 \pm 0.8$ & $13.3 \pm 0.9$ \\
\hline A. alternata LG14 & $17.4 \pm 0.9$ & $20.5 \pm 1.5$ & $22.3 \pm 0.4$ & $19.2 \pm 2.1$ & $10.9 \pm 0.7$ \\
\hline A. solani & $16.9 \pm 2.3$ & $19.1 \pm 0.7$ & $19.3 \pm 1.4$ & $17.8 \pm 1.9$ & $18.4 \pm 1.2$ \\
\hline R. solani & $17.7 \pm 1.3$ & $18.3 \pm 0.3$ & $20.0 \pm 0.7$ & $19.9 \pm 1.1$ & $15.5 \pm 1.1$ \\
\hline B. cinerea & $-*$ & $15.4 \pm 1.1$ & $19.8 \pm 1.8$ & $13.1 \pm 1.4$ & - \\
\hline F. solani & $18.7 \pm 1.2$ & $20.0 \pm 1.0$ & $22.0 \pm 0.6$ & $20.0 \pm 1.0$ & $18.7 \pm 1.3$ \\
\hline F. oxysporum & - & $13.1 \pm 2.0$ & $17.0 \pm 1.0$ & $15.1 \pm 3.1$ & $15.2 \pm 0.3$ \\
\hline S. sclerotiorum & - & $20.1 \pm 0.4$ & $20.7 \pm 0.1$ & $31.5 \pm 2.3$ & - \\
\hline
\end{tabular}

Note: $\mathrm{p}=0.05$

* experiment was not conducted 
According to data from Table 2, studied strains of streptomycetes had the ability to manifest antagonism against phytopathogenic fungi in varying degrees. For example, against $A$. alternata was identified 1 strain capable to inhibit its growth $(S . s p .10)$ and 2 strains, under which action of their metabolites studied phytopathogen was suppressed by $12.5-14.0 \mathrm{~mm}$ (S. sp. 9 and 66). Other strains of streptomycetes inhibited growth of this test culture in a less degree (the radius of zone of growth inhibition was 8.0$9.5 \mathrm{~mm}$ ). Strains of streptomycetes showed next results against $A$. solani as follows: $S$. sp. 10 did not have the ability to completely suppress the growth of this fungus test, the radius of zone of growth inhibition was $14.5 \mathrm{~mm}$, for other strains the antifungal activity was slightly higher than in relation to A. alternata.

The ability to delay the active growth of $A$. niger was noted only for strain $S$. sp. 66 (the radius of the zone was up to $14.5 \mathrm{~mm}$ ); in other strains the radius of the zones of growth inhibition of this test culture ranged from 5.5 to $11.0 \mathrm{~mm}$. For $B$. cinerea, it was also possible to identify active antagonists strain $S$. sp. 10, which has the ability to completely inhibit the growth of this phytopathogen, and strain $S$. sp. 9, whose metabolites also actively inhibited fungal growth (zone radius up to $14.5 \mathrm{~mm}$ ).

Among representatives of the genus Fusarium were selected 3 strains F. oxysporum, F. solani, F. culmorum. An active antagonist in relation to these test cultures was streptomycete $S$. sp. 9, the radius of the zone of growth inhibition of these phytopathogens was $14.5-17.0 \mathrm{~mm}$. The ability to actively retard growth was also noted for strain $S$. sp. 185, but only for $F$. oxysporum zones up to $14.0 \mathrm{~mm}$, while strain $S$. sp. 66 caused the formation of a lack of growth zone of not more than $7.5 \mathrm{~mm}$. So, it should be noted that among 7 strains of streptomycetes studied, only 3 had the ability to manifest antagonism against $F$. oxysporum, and in relation to another representative of genus Fusarium - F. solani; were detected 5 strains with antifungal activity of varying degrees (radius of the zone ranged between 5.0-9.5 and even $14.5 \mathrm{~mm}$ ). For F. culmorum, 6 strains of streptomycete antagonists were detected, the radius of the zone of growth inhibition varied from $9.0 \mathrm{~mm}$ (S. sp. 185) to $20.0 \mathrm{~mm}$ (S. sp. 66). By comparison the antifungal activity of the streptomycetes strains studied against $S$. sclerotiorum, it should be noted that for 2 strains of $S$. spp. 10 and 185 it was absent, for $S$. spp. 12, 19 and 44 it was not high (radius of the zones varying between $8.5-11.5 \mathrm{~mm}$ ). Metabolites of $S$. sp. 66 caused the formation of zones with a radius of till $14.0 \mathrm{~mm}$ and only one strain of $S$. sp. 9 is able to completely suppress the growth of this phytopathogen.

Further, an experiment was conducted on the effect of bacterial suspensions of genus Bacillus on the germination of conidia A. alternata. In experiment 5 bacteria were used, shown in Table 1.

Germination of conidia of Alternaria in a nutrient medium (control 2) in a $1 \%$ solution after 2 hours exposure was initiated by normal sprouts. After 4 hours, more than $50 \%$ of the conidia had already germinated, whereas in water (control 1) $50 \%$ germination was observed only after 6 hours of exposure. The titer of the bacteria used in the experiment was: B. subtilis 
26D $1.4 \times 10^{10} \mathrm{CFU} / \mathrm{ml}$; B. subtilis $\mathrm{S} 16-4.1 \times 10^{9} \mathrm{CFU} / \mathrm{ml}$; B. subtilis $\mathrm{S} 2-$ $3.1 \times 10^{9} \mathrm{CFU} / \mathrm{ml}$; B. subtilis $\mathrm{S} 4-2.3 \times 10^{8} \mathrm{CFU} / \mathrm{ml}$; B. subtilis $\mathrm{S} 22-2.5 \times$ $\times 10^{9} \mathrm{CFU} / \mathrm{ml}$.

Table 2

Antifungal activity of streptomycetes of soils of Moldova

\begin{tabular}{|l|c|c|c|c|c|c|c|}
\hline \multirow{2}{*}{ Test cultures } & \multicolumn{7}{|c|}{ Radius of zones of growth inhibition, (mm) } \\
\cline { 2 - 8 } & S. sp. 9 & S.sp. 10 & S. sp. 12 & S. sp. 19 & S. sp. 44 & S. sp. 66 & $\begin{array}{c}\text { S. sp. } \\
185\end{array}$ \\
\hline A. alternata & $14.0 \pm 1.0$ & C.i.* & $12.5 \pm 0.7$ & $8.0 \pm 0.7$ & $9.5 \pm 1.0$ & $12.5 \pm 0.7$ & $8.5 \pm 0.3$ \\
\hline A. solani & $15.0 \pm 0.7$ & $14.5 \pm 0.6$ & $14.0 \pm 0.3$ & 0 & $9.0 \pm 0.3$ & $13.5 \pm 1.0$ & $9.0 \pm 0.1$ \\
\hline A. niger & $9.5 \pm 0.1$ & $11.0 \pm 0.1$ & $8.5 \pm 0.1$ & $10.0 \pm 0.2$ & 0 & $14.5 \pm 1.3$ & $6.5 \pm 0.1$ \\
\hline B. cinerea & $14.5 \pm 0.3$ & C.i. & $11.0 \pm 0.1$ & $10.0 \pm 0.1$ & $10.0 \pm 0.2$ & $10.0 \pm 0.2$ & $8.0 \pm 0.1$ \\
\hline R. solani & $14.5 \pm 0.7$ & 0 & $8.5 \pm 0.5$ & $10.0 \pm 1.0$ & 0 & 0 & 0 \\
\hline F. oxysporum & $17.0 \pm 0.5$ & 0 & 0 & 0 & 0 & $15.0 \pm 0.5$ & $28.0 \pm 2.2$ \\
\hline F. solani & $14.5 \pm 0.5$ & $7.0 \pm 0.1$ & $8.5 \pm 0.1$ & $12.0 \pm 0.7$ & 0 & $7.5 \pm 0.1$ & 0 \\
\hline F. culmorum & $16.0 \pm 0.8$ & $11.0 \pm 0.1$ & $19.0 \pm 0.7$ & $10.0 \pm 0.2$ & 0 & $20.0 \pm 1.2$ & $9.0 \pm 0.1$ \\
\hline S. sclerotiorum & C.1. & 0 & $11.5 \pm 0.1$ & $10.0 \pm 0.1$ & $8.5 \pm 0.1$ & $14.0 \pm 1.0$ & 0 \\
\hline
\end{tabular} $\begin{aligned} & \text { Note: } \text { p=0.05 } \\
& * \text { complete inhibition }\end{aligned}$

In solutions of all bacterial cultures, there was no normal germination of conidia. The strongest inhibitory effect of conidia was shown by the S2 culture. At a concentration of $10 \%$ only after 24 hours, tumor-like outgrowths appeared (Fig. 1b). At initial concentrations, no germination of conidia was observed in any of the cultures studied.
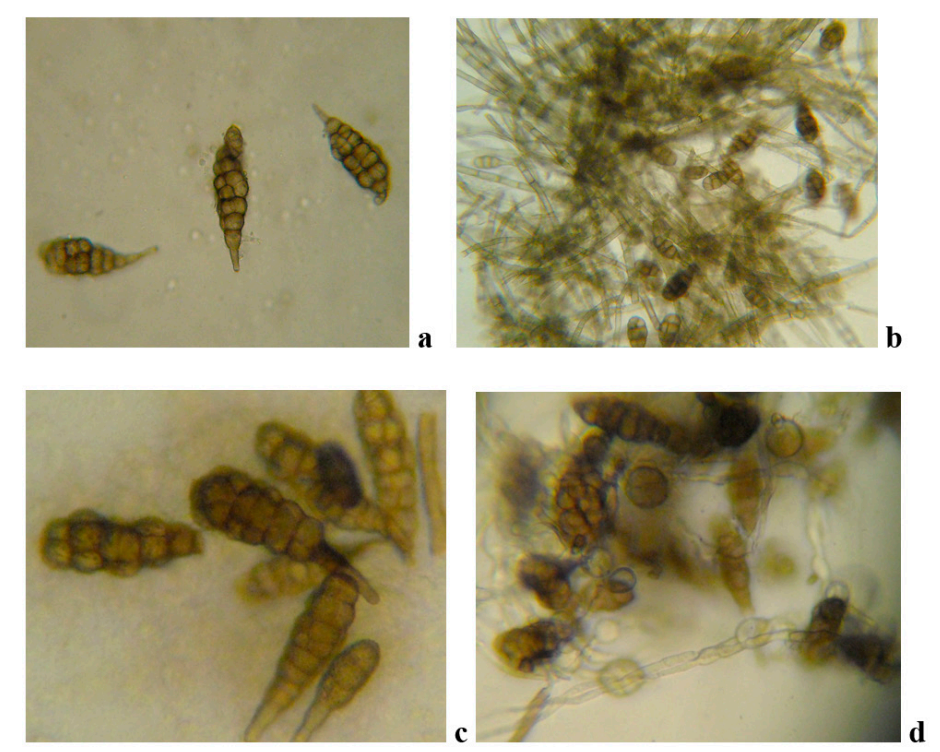

Fig. 1. Conidia Alternaria alternata: a) normal appearance of conidia $(12 \times 40$ magnification) and after 24 hours of exposition: b) in water (12×20 magnification), c) in $50 \%$ solution $\mathrm{S} 2$, d) $10 \%$ solution $\mathrm{S} 2(12 \times 40$ magnification) 

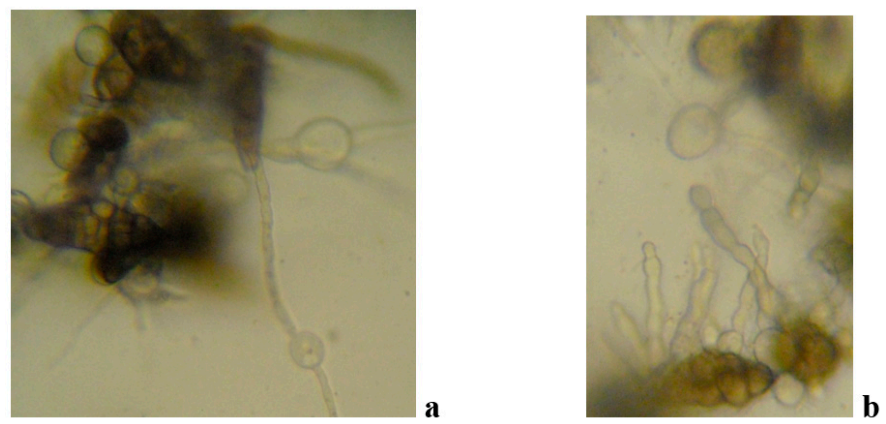

Fig. 2. Conidia Alternaria alternata

a) $50 \%$ sol. S4 (36 h), b) $10 \%$ sol. S4 (48 h) (12×40 magnification)

Tumor formation did not allow further development of the normal mycelium after 36 hours and 48 hours of conidia in bacterial solutions of suspensions along all dilutions (Fig. 2). With regard to the influence of metabolites of bacteria genus Bacillus on the germination of conidia, it can be assumed that the strains secrete exometabolites, which have the ability to completely inhibit the reproduction of the fungus.

Discussion. Considering the actual problems of biotechnology in crop production, many researchers believe that further development will be directed to the use of natural and synthetic growth regulators and microbial preparations in biotechnology to protect them from diseases, which will solve a significant part of the food program against the expected rapid population growth in developed countries [9-11].

The prospects for the use of substances with antimicrobial activity of microbial origin are associated with their relatively weak toxicity to humans and animals in comparison with chemical means of protection by the specificity action of ability to penetrate into plant tissues and high activity against pathogens [8, 12-15].

According to the literature, industrial strains have a wide spectrum of antagonistic activity against various species of phytopathogenic fungi and bacteria. They produce lytic enzymes, synthesize cyanides and other antifungal metabolites, able to stimulate plant growth due to biosynthesis of phytohormones-auxin derivatives [16]. When inoculating tomatoes, they reduced the number of plants affected by phytopathogenic $F$. oxysporum by 2.5 times, the number of fungi on the roots was by 6.9 times lower than in the variant without inoculation with this strain. This strain was isolated from the chernozem soil of the Republic of Moldova [17]. Another strain of Ch-13 formed the basis of Bisalbisan, registered as a fungicide of etched wheat [18].

Being progeny of the ancient inhabitants of the Earth, prokaryotic organisms, including streptomycetes, no doubt, could also enter into various relationships with higher forms of life, and first of all with plants at all stages of the evolution of the lasts [19].

Being in the rhizosphere and having the ability to form various physiologically active substances, they play an essential role in the life of plants $[14,20]$. 
Actinomycetes are very well-known saprophytic bacteria, which have a qualitative and quantitative value in the rhizosphere, where they can influence the growth of plants and protect them against pathogenic fungi. Up to $70 \%$ of actinomycetes, especially representatives of the genus Sterptomyces, are the source of more than $70 \%$ of all antibiotics [21-25].

Comparing the antifungal activity of the studied strains of genus Bacillus and genus Streptomyces, isolated from the soil of the central part of Moldova, it is shown, mainly, the strains of the genus Bacillus showed it to a much greater extent than representatives of the genus Streptomyces - the radius of the zones of growth inhibition of such causative agents as Alternaria alternata 2-14 and Alternaria alternata LG14 was greater than the representatives of the genus Streptomyces (radius value from 17.0 to $22.5 \mathrm{~mm}$ ), however, it should be noted that among the strains of the genus Streptomyces was a strain that completely suppressed the growth of Alternaria alternata (Tables 1 and 2) $-S$. sp. 10. The same strain also had the ability to completely suppress the growth of another phytopathogen, $B$. cinerea, whereas among the representatives of the genus Bacillus only in B. subtilis-S2 was observed a sufficiently high activity (radius of the zone up to $19.8 \mathrm{~mm}$ ), and in the remaining strains it was smaller (radius of the zones from 8.0 to $15.4 \mathrm{~mm}$ ).

In the literature of recent years, there are numerous data on inhibition of mycelial growth, spore germination of $B$. cinerea and representatives by strains genera Fusarium and Streptomyces [23, 26-34]. Among the isolated strains, it can also pay attention to the activity of antagonists to $F$. solani, among the representatives of the genus Bacillus is a strain of $B$. subtilis - S2 (radius $22.0 \mathrm{~mm}$ ).

B. subtilis - S4 and S16 (radius $20.0 \mathrm{~mm}$ ), and among the representatives of the genus Streptomyces - strain $S$. sp. 9 (radius $-14.5 \mathrm{~mm}$ ) and $S$. sp.185 (radius $18.0 \mathrm{~mm}$ ). In relation to other representatives of the genus Fusarium against F. oxysporum activity was lower as representatives of the genus Bacillus, so representatives of the genus Streptomyces: the radius of the zones of strains genus Bacillus ranged from 13.0 to $17.0 \mathrm{~mm}$, and for the genus Streptomyces - from $7.5 \mathrm{~mm}$ to $17.0 \mathrm{~mm}$. The data obtained by us is in accorance with literature data, in particular, that among 397 strains of actinomycetes only $9 \%$ were active against $F$. oxysporum and against $B$. cinerea, and $18.7 \%$ against $A$. niger. Only $2 \%$ of the strain of actinomycetes delayed the growth of all test cultures [35]. An active antagonist against $B$. cinerea, F. solani, A. alternata is also considered streptomycetes $S$. rimosus [36].

With regard to $A$. niger, in our studies among strains of streptomycetes we were able to find a strain that could inhibit the growth of this phytopathogen. The radius of the zones of growth inhibition of this test culture ranged from 6.25 to $11.0 \mathrm{~mm}$, and only under the influence of the metabolites of the strain $S$. sp. 66 they were larger (up to $14.5 \mathrm{~mm}$ ).

For $R$. solani, in our opinion, two strains of the present bacteria can be considered an active antagonist. Bacillus - B. subtilis $\mathrm{S} 2$ and B. subtilis $\mathrm{S} 4$, since their metabolites caused the appearance of zones of non-growth of this phytopathogen with a radius of $19.9-20.0 \mathrm{~mm}$, whereas to other studied bacteria the antifungal activity was less (radius of the zones from 17.7 to $18.3 \mathrm{~mm}$ of the representatives of the Bacillus and from 8.5 to $14.5 \mathrm{~mm}$ of S. sp. 12 and 9). 
Special attention should be paid to the search for antagonists against $S$. sclerotiorum. Experiments have shown that the growth of this pathogen actively delayed 3 strains of Bacillus (B. subtilis $\mathrm{S} 2$, B. subtilis $\mathrm{S} 4$, B. subtilis S16) - the radius of the zones of growth absence under the influence of their metabolites reached 20.1-20.7 mm, and B. subtilis S4 metabolites more inhibited the growth of $S$. sclerotiorum and the zone of absence of growth reached up to $31.5 \mathrm{~mm}$ radius.

No less interesting were results of the determination of antifungal activity against $S$. sclerotiorum of the strains streptomycetes studied. For example, metabolites of strains $S$. spp. 12, 19, and 44 caused the formation of non-growth zones of a test culture with a radius of $5.0-10.75 \mathrm{~mm}$, but metabolites of $S$. sp. 66 were more active (zones up to $14.0 \mathrm{~mm}$ ). The greatest interest among streptomycetes strains isolated from the soil of Moldova is represented by S. sp. 9, since its metabolites caused complete inhibition of the growth of this phytopathogen (Table 2).

On the ability of soil streptomycetes to affect the growth of $R$. solani there are few literature data. For example, according to Reruanul M.I. (2009), among strains isolated from the soil of Korea, only ethyl acetate extract of $S$. abidoflavus showed inhibition of the mycelial growth of $R$. solani in Petri dishes by $60.27 \%$. Studies on the possibility of inhibition of $R$. solani RRC-9 showed that metabolites of $S$. philanti RM-1-138 synthesized on 14th day of growth are more active than the complex of substances on the 7th day. Since on the 7th day this complex includes 17 compounds, and on the 14th already 36 substances [37, 38].

Three strains of B. subtilis - S2, S4 and S16 showed high antifungal properties against to such causative agents of diseases of agricultural plants of early blight and root rot of tomatoes. If control strain caused the appearance of zones of growth inhibition in these pathogens with a radius of $17.4-18.7 \mathrm{~mm}$, then under the influence of metabolites of strains of the genus Bacillus, isolated from the soil of Moldova, the radius of the zones varied from 17.8 to $22.3 \mathrm{~mm}$, by 1.3 times more than in the control.

It should also be noted that strain $S$. sp. 10 is important because of ability to inhibit growth of $A$. solani with a radius up to $14.5 \mathrm{~mm}$ and $S$. spp. 12 and 66, capable to inhibit growth of $F$. culmorum with a radius of 19.0-20.0 mm. Special attention should be paid to strains $S$. spp. 9 and 10, which have the ability to completely inhibit the growth of A. alternata, $S$. sclerotiorum and B. cinerea.

Among bacterial organisms, a group of aerobic spore-forming bacteria is known for its pronounced antagonistic properties in relation to a large number of phytopathogenic microorganisms. Spore-forming bacteria can be placed on a par with actinomycetes, penicilliums and treat them as the main sources of antibiotic substances.

All bacterial cultures of the genus Bacillus showed an inhibitory effect on the germination of conidia. As mentioned earlier, the conidia had an outlet of the contents in the form of spherical outgrowths.

The same effect of action of B. subtilis was noted by Kolomietz A.I. et al. (2007) against Penicillium expansum and Botrytis cinerea, then group of scientists from Korea observed the action of Bacillus amyloliqufaciens on the pathogenic fungus Botrytis cinerea, morphological changes in the growth of its mycelium $[5,39]$. These were the structures of a spherical species. The 
same changes in the morphology of the mycelium were formed in Sclerotinia sclerotiorum during co-cultivation with Bacillus subtilis K-1-1 [15].

The experiments showed that B. subtilis $\mathrm{S} 4$ showed the least inhibitory effect, it can be explained by the fact that the nutritive medium on which the culture was grown is not suitable medium for this strain to accumulate biomass and / or release of antibiotic substances. To demonstrate high antagonistic activity, strains need high density, at the same time an increase in the concentration of bacterial cells leads to inhibition of plant growth. Therefore, for strains with strong antagonistic activity against phytopathogens and plant growth, such a contradiction properties is probably reflected by decrease of application in agriculture [40].

According to results, strain $B$. subtilis $\mathrm{S} 2$ showed a high inhibitory effect on all used test cultures of phytopathogens. B. subtilis $\mathrm{S} 4$ is distinguished by the inhibitory effect of $S$. sclerotiorum - agent of white rot (1.5 times higher than other Bacillus strains studied), and on other test cultures its effect was at the level of other strains. Between representatives of Streptomyces spp., it should be noted strain $S$. sp. 9 (all test cultures have growth inhibition zones and even complete suppression of $S$. sclerotiorum), S. sp. 10 (complete suppression of the causative agent of gray rot $-B$. cinerea) and $S$. sp. 185 (pathogenic growth delay zones of $F$. oxysporum are by 1.5 and 1.8 times more than strains $S$. spp. 9 and 66, and inhibition is absent for other strains).

Conducted researches show extensive and diverse choice of microorganisms as alternative source of biopreparation in comparison with chemical preparations.

Thus, the data obtained after our studies on the antifungal activity of bacteria of genera Bacillus and Streptomyces isolated from rizosphere of tomatoes and from the soil samples of the central part of Moldova show the perspective of bacterial organisms in the control of phytopathogens, and possibly, as a basis for biopreparations for the protection of agricultural plants, especially vegetable crops.

\title{
АНТИФУНГАЛЬНА АКТИВНІСТЬ БАКТЕРІЙ РОДІВ ВАCILLUS I STREPTOMYCES, ВИДІЛЕНИХ 3 ГРУНТУ МОЛДОВИ
}

\author{
В. Шубіна ${ }^{1}$, М. Бирса ${ }^{2}$ С. Бурцева ${ }^{2}$ \\ ${ }^{1}$ Інститут генетики, фізіології $і$ захисту рослин, \\ вул. Лісна 20, Кишинів, МD-2002, Республіка Молдова \\ ${ }^{2}$ Інститут мікробіології $і$ біотехнології, \\ вул. Академічна 1, Кишинів, МD-2002, Республіка Молдова \\ Резюме
}

Мета. У статті представлені результати досліджень, метою яких було визначення антифунгальної активності штамів родів Bacillus i Streptomyces, виділених з грунту Молдови, по відношенню до фітопатогенних грибів, широко поширених в Молдові. Методи. Штами вирощували на класичних агаризованих середовищах, антифунгальну активність визначали методом агарових блоків з тест-культурами - фітопатогенними грибами, а біологічним еталоном була бактерія B. subtilis 26D. У дослідах по проростанню конідій A. alternata використовували 5 бактеріальних культур, 
що вирощували на рідкому поживному середовищі № 2. Результати. Встановлено, що всі бактерії p. Bacillus проявляють антифунгальну активність по відношенню до тест-культур, але в різному ступені. Найменше пригнічувався ріст $B$. cinerea i F. oxysporum. Найбільш активно пригнічував ріст S. sclerotiorum штам S4. Серед стрептоміцетів знайдений штам ( $S$. sp. 10$)$, здатний повністю пригнічувати ріст A. alternata i B. cinerea, i штам $S$. sp 9, який повністю пригнічував ріст $S$. sclerotiorum. Активно затримували ріст F. culmorum 3 штами (штам 9, 12 і 66, радіус зон - від 16,0 до 20,0 мм), а штам $S$. sp. 185 - по відношенню до F. oxysporum (зони до 28,0 мм). Найбільшу інгібуючу дію на проростання конідій A. alternata мав штам S2. Висновки. Порівняльна оцінка антифунгальної активності ризосферних штамів B. subtilis виявила штам з найбільш вираженими антифунгальними властивостями. Досліджувані рідкі культури бактерій роду Bacillus проявили високу фунгіцидну дію на проростання конідій A. alternata. 37 перевірених штамів стрептоміцетів найбільшу зацікавленість представляє штам $S$. sp. 10, здатний повністю пригнічувати ріст A. alternata i $B$. cinerea, i штам $S$. sp. 9, що повністю пригнічує ріст S. sclerotiorum, а також штам $S$. sp. 185, який активно затримує ріст F. охуsporum, і штам $S$. sp. $10-$ A. solani.

Ключові слова: Bacillus, Streptomyces, проростання конідій, фітопатогени.

\title{
АНТИФУНГАЛЬНАЯ АКТИВНОСТЬ БАКТЕРИЙ РОДОВ ВА- CILLUS И STREPTOMYCES, ВЫДЕЛЕННЫХ ИЗ ПОЧВЫ МОЛ- ДОВЫ
}

\author{
В. Шубина ${ }^{1}$, М. Бырса ${ }^{2}$ С. Бурцева ${ }^{2}$ \\ ${ }^{1}$ Институт генетики, физиологии и защиты растений, \\ ул. Лесная 20, Кишинев, МD-2002, Республика Молдова \\ ${ }^{2}$ Институт микробиологии и биотехнологии, \\ ул. Академическая 1, Кишинев, МD-2028, Республика Молдова
}

\section{Резюме}

Цель. В статье представлены результаты исследований, целью которых являлось определение антифунгальной активности штаммов родов Bacillus и Streptomyces, выделенных из почвы Молдовы, по отношению к фитопатогенным грибам, широко распространенным в Молдове. Методы. Штаммы выращивали на классических агаризованных средах, антифунгальную активность определяли методом агаровых блоков с тест-культурами - фитопатогенными грибами, а биологическим эталоном служила бактерия B. subtilis 26D. В опытах по прорастанию конидий A. alternata использовали 5 бактериальных культур, выращиваемых на жидкой питательной среде № 2. Результаты. Установлено, что все бактерии р. Bacillus проявляют антифунгальную активность по отношению к тест-культурам, но в разной степени. Менее всего подавлялся рост $B$. cinerea и $F$. oxysporum. Наиболее активно подавлял рост $S$. sclerotiorum штамм S4. Среди стрептомицетов найден штамм (S. sp. 10), способный полностью подавлять рост A. alternata и $B$. cinerea, и штамм $S$. sp 9, полностью подавляющий рост $S$. sclerotiorum. Активно задерживали рост $F$. culmorum 3 штамма (штамм 9, 12 и 66, радиус зон - от 16,0 до 20,0 мм), а штамм $S$. sp. 185 - по отношению к $F$. oxysporum (зоны до 28,0 мм). Самое сильное ингибирующее действие на прорастание конидий A. alternata оказал штамм S2. Выводы. Сравнительная оценка 
антифунгальной активности ризосферных штаммов B. subtilis выявила штамм с наиболее выраженными антифунгальными свойствами. Исследуемые жидкие культуры бактерий рода Bacillus проявили высокое фунгицидное действие на прорастание конидий A. alternata. Из 7 проверенных штаммов стрептомицетов наибольший интерес представляет штамм $S$. sp. 10, способный полностью подавлять рост A. alternata и $B$. cinerea, и штамм $S$. sp. 9, полностью подавляющий рост $S$. sclerotiorum, а также штамм $S$. sp. 185, активно задерживающий рост $F$. охуsporum, и штамм $S$. sp. $10-$ A. solani.

Ключевые слова: Bacillus, Streptomyces, прорастание конидий, фитопатогены.

1. Monastirski OA. [Modern trends in the creation and practical application of protective biopreparations and biotechnologies in plant growing]. In: Materials of the international scientific-prac. conf., Biological protection of plants, as a basis for ecological and phytosanitary stabilization of agroecosystems; 2010; Krasnodar, Russia; 2010; p. 335-42. Russian.

2. Pavliushin VA. [Problems of modern plant protection]. In: Materials of the international scientific conferences ,The problems of mycology and phytopathology in the 21st century"; 2013; Sankt-Petersburg, Russia, 2013. p. 202-5. Russian.

3. Grishechikin LD, Koreniuk EF, Miliutenkova TI, Silaev AI. [Microbiological preparations based on Bacillus subtilis for the protection of crops against diseases]. In: Materials of the International Scientific and Practical Conference "Biological protection of plants - the basis of stabilization of agroecosystems"; 2010; Krasnodar, Russia, 2015; p. 407-9. Russian.

4. Maksimov IV, Pusenkova LI, Abizghildina RR. [Preservation of the protective potential of biologics in potato tubers in the post-vegetation period]. In: Materials of the international scientific-prac. conf., Biological protection of plants, as a basis for ecological and phytosanitary stabilization of agroecosystems; 2010; Krasnodar, Russia; 2010; p. 448-51. Russian.

5. Kolomietz AI, Kuptsov VN, Romanovskaia TV, Sviridov AV, Kilichevskaia OV. [Scientific and practical basis for creating a biological product for the protection of sugar beet from storage rot]. Inform. IOMB Bulletin of Sankt-Peterburg. 2007; 38:145-147. Russian.

6. Singh AK, Chhatpar HS. Purification, Characterization and Thermodynamics of Antifungal Protease From Streptomyces sp. A6. J. Basic. Microbiol. 2011; 51(4):424-432.

7. Lio L, Cao L, Xiao S. Screening and Bioactivity of Antagonistic Microbial Agents Against Phytophthoric Blight on Pepper. J. Shenyang Agr. Univ. 2008; 39(2):313-317.

8. Egorov NS. [The fundamentals of the doctrine of antibiotics]. Ed. Moscow State University: Moscow; 2004. Russian.

9. Burril SG, Roberts WJ. Biotechnology and Economic Development, the Winning Formula. Biotechnology. 1992; 10(6):647-653.

10. Dolgich YI. [Actual problems of biotechnology in plant growing]. Plant Physiology. 1996; 44(6):630-633. Russian.

11. Galindo E, Ramirez OT. Bioprocess engineering. Trends Biotechnol. 1998; 16(7):282-283. 
12. Azizbekean RR. [The use of spore-forming bacteria as biological plant protection products]. Biotehnologia. 2013; 1:69-77. Russian.

13. Hairullin RM, Egorshina AA, Lukiantsev MA, Urazbahtina NA, Irgalina RS, Sahabutdinova AR. [Biological features of endophytic strains of Bacillus subtilis as promising bases of new biopreparations]. Agrarian Russia. 2011; 3:49-53. Russian.

14. Novikova II, Boikova IV, Shenin ID. [Biological features and component composition of the active complex of Streptomyces chrysomallus P-21 strain of phytopathogenic fungi]. Plant Protection Newsletter. 2006; 3:13-21. Russian.

15. Zaharchenko NS, Gheorghievskaia EB, Shkolinaya AA, Yuhmanova AA, Kashparov IA, Burianov EI, et. al. [Isolation and characterization of the Bacillus subtilis K-1-1 polypeptide, a growth inhibitor of phytopathogenic fungi and bacteria]. Biotehnologia, 2007; 3:21-26. Russian.

16. Zavkelova EA, Klimova SI, Cherdintseva TA, Netrusov AI. [Microorganisms - producers of plant growth stimulants and their practical application (review)]. Applied Bioch. Microb. 2006; 42(2):133-143. Russian.

17. Chebotari VK, Makarova NM, Shaposhnikov AI, Kravchenko LV. [Antifungal and phytostimulating properties of the rhizosphere strain Bacillus subtilis Ch-13 - producer of bio drugs]. Applied Bioch. Microb. 2009; 45(4):419-423. Russian.

18. Tihonovich IA, Kruglov IV. [Biopreparations in agriculture. Methodology and practice of application of microorganisms in plant growing and fodder production]. Izd. Rosselkhozakademiya: Moscow; 2005. Russian.

19. Kalakutskii LV, Sharaea LS. [Actinomycetes and higher plants]. Successes of microbiology. 1990; 24:26-64. Russian.

20. Vozneakovskaya IM. [Presowing stimulation of seeds by microorganisms - producers of vitamins]. In: All-Soviet Conference "Microorganisms - stimulants and inhibitors of plant and animal growth"; 1989; Tashkent, USSR, 1989. p. 67. Russian.

21. Atta HM. An Antifungal Agent Produced by Streptomyces olivaceiscleroticus AZ-SH 514. World Applied Sci. J. 2009; 6(11):1495-1505.

22. Cao L, Qui L, You J, Tan H, Zhou S. Isolation and Characterization of Endophytic Streptomyces Strain From Surface Sterilized Tomato (Lycopersicon esculentum) Roots. Lett. Appl. Microbiol. 2004; 39(5):425-430.

23. Elkahoui S, Djubali N, Karkouch J, Hadj Ibrahim A, Kalai L, Bachkovel S, Tabbene O, Limam F. Mass Spectrometry Identification of Antifungal Lipopeptides From Bacillus sp. BCLRB 2 Againts Rhizoctonia solani and Sclerotinia sclerotiorum. Prikl. Biokhim. Mikrobiol. 2014; 50(2):184-188.

24. Kuzikova IL, Suharevich VI, Shenin ID, Medvedeva NG. [Biological properties and identification of polyene antifungal antibiotic, promising for protection against mycorrhages]. News of RAS. Ser. Biol. 2010; 2:238-247. Russian.

25. Sacramento DR, Coelho RRR, Wigg MD, Toledo LF, dos Santos MGM. Antimicrobial and Antiviral Activities of an Actinomycete (Streotomyces sp.) Isolated From a Brazilian Tropical Forest Soil. World J. Microbiol. Biotechnology. 2004; 20(3):225-229.

26. Bouizgarne B, El Hadrami I, Ouhdouh Y. Novel Production of Isochainin by a Strain of Streptomyces sp. Isolated From Rhizosphere Soil of the Indigenous Moroccan Plant Argania spinosa L. World J. Microbiol. Biotechnology. 2006; 22(5):423-429. 
27. Jeffrey LSH. Isolation, Characterization and Identification of Actinomycetes From Agriculture Soil at Semongok, Sarawak. African Journal of Biotechnology. 2008; 7(20):3697-3702.

28. Koch E, Loffen I. Psartial Characterization of the Antimicrobial Activity of Streptomyces antimycoticus FZB 53. J. Phytopathology. 2007; 157(4):235-242.

29. Kuzin AI, Kuznetsova NI, Nikolaienko MA, Azizbakean RR. [Strain Bacillus amylolyquefaciens $16-\mathrm{K} 11$, which has a fungicidal activity against the causative agents of fusariosis of cereals]. Biotehnologia. 2013; 5:31-39. Russian.

30. Li Q, Ning P, Zhang L, Huang J, Li G, Hsiang T. Effects of Volatile Substances of Streptomyces globisporus JK-1 on Control of Botrytis cinerea on Tomato Fruit. Biol. Control. 2012; 61(2):113-120.

31. Liu Q, Yu J, Yan J, Qi X, Liu C. Antagonism and action mechanism of antifungal metabolites from Streptomyces rimosus MYO 2. J. Phytopathology 2009; 157 (5):306-310.

32. Tran DQ. [Noing nghiep cong nghiep thue pham]. Agr. and Food ind. 1996; 5:179-182. Vietnamese.

33. Wang C, Wang Z, Qiao X, Li Z, Li F, Chen M, Wang Y, Huang Y, Cui H. Antifungal Activity of Volatile Organic Compounds From Streptomyces alboflavus ID-1. FEMS Microbiol Lett. 2013; 341(1):45-51.

34. Zhao S, Du CM, Tian CY. Suppresion of Fusarium oxysporum and Induced Resistance of Plants Involved in the Biocontrol of Cucumber Fusarium Wilt by Streptomyces bikiniensis HD-087. World J. Microbiol. Biotechnology. 2012; 28(9):2919-2927.

35. Buzyak A, Vanko I, Gromiko O, Fedorenko V. Fungizidni vlastivosti gruntovih aktinimizetiv, vidilenih s pivdennogo shilu g. Kishka na Krimskomu pivostrovi. In: Proceding of the VI International young Scientists conference "Biodiversity. Ecology. Adaption. Evolution.”; 2013, May 13-17; Odessa, 2013. p. 262-3. Ukrainian.

36. Liu Q, Wu YH, Lu JC. Screening of Antagonistic Actinomycetes From Greenhouse Soil in Northeast China. Soils. 2004; 36(5):573-575.

37. Boukaew S, Plubrukam A, Prasertsan P. Effect of Volatile Substances From Streptomyces philanthi RM-1-138 on Growth of Rhizoctonia solani on Rice Leaf. Journal of the International Organization for Biological Control. 2013; 58(4):471-482.

38. Reruanul MI, Yong TJ, Jeon JR, Chi HS, Jong SL. Isolation, Identification and Optimal Culture Conditions of Streptomyces albidoflavus C 247 Producing Antifungal Agents Against Rhizoctonia solani AG 2-2. Mycobiology. 2009; 37(2):114-120.

39. Seung HJ, Harayan CP, Jian XD, Young SK, Bong-Sik Y, Seung HY. Biocontrol Activity of Bacillus amyloliquefaciens CNU 114001 Against Fungal Plant Diseases. Mycobiology. 2013; 41(4):234-242.

40. Lukiantsev MA. [Peculiarities of biological activity of endophytic strains of Bacillus subtilis Cohn with different antagonism to phytopathogenic fungi]. PhD Abstractthesis: Saratov; 2010. Russian.

Отримано 31.05.2018 